Doi: $10.15863 /$ TAS

\section{International Scientific Journal}

\section{Theoretical \& Applied Science}

p-ISSN: 2308-4944 (print) e-ISSN: 2409-0085 (online)

Year: $2015 \quad$ Issue: $01 \quad$ Volume: 21

Published: $30.01 .2015 \quad$ http://www.T-Science.org
Lyudmila A. Gerasimova

Candidate of biological sciences, Docent

Siberian state aerospace university named after academician M.F. Reshetnev (SibSAU), Russia

lyu-gerasimova@yandex.ru

Irina Y. Eremina

Candidate of biological sciences, Docent Krasnoyarsk state agricultural university, Russia irin-eremina@yandex.ru

Anna I. Kuklina

senior lecturer,

Siberian state aerospace university named after academician M.F. Reshetnev, Russia

aikuklina@mail.ru

\title{
RETROSPECTIVE ERYTHROCYTE ANTIGENS ANALYSIS OF THE GENE POOL OF RED-AND-WHITE DAIRY CATTLE POPULATION
}

Abstract: The basic gene pool of JSC «Borodino stud-farm» cattle population was estimated. The lines of purebred Holstein Friesians, a group of Simmental breed cattle and their cross-breeds are considered. Immunogenetic breed markers are presented.

Key words: gene pool, immunogenetic estimation, Holstein Friesian cattle breed, Simmental cattle breed, F1 hybrids, immunogenetic markers.

Language: English

Citation: Gerasimova LA, Eremina IY, Kuklina AI (2015) RETROSPECTIVE ERYTHROCYTE ANTIGENS ANALYSIS OF THE GENE POOL OF RED-AND-WHITE DAIRY CATTLE POPULATION. ISJ Theoretical \& Applied Science 01 (21): 94-98. doi: http://dx.doi.org/10.15863/TAS.2015.01.21.17

Introduction. Nowadays the issues of ecological monitoring of agricultural animals populations are of great importance because the problem of providing the population with livestock products is far from being solved. The immunogenetic analysis the basis of which is the theory of genetic markers is one of the most informative methods of assessment of direction and dynamics of population processes.

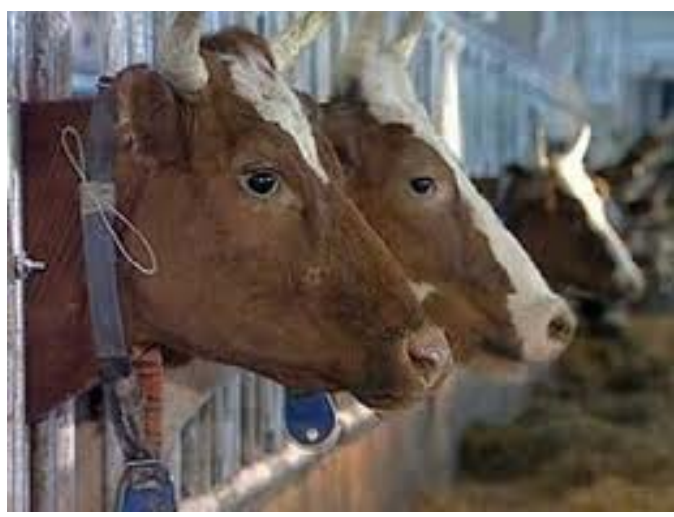

Figure 1 - Cows of JSC "Borodino stud-farm" (photo from [1])
Domestic experience shows that the increase of the productivity genetic potential by traditional pure breeding on the basis of one's own breeding resources is only $1.0-1.5 \%$ per year, or no more than $40-50 \mathrm{~kg}$ of milk. The use of cross-breeding with attraction of the best specialized breeds of the world can accelerate the growth of productivity of cows 2-3 times [3, 4].

Immunogenetic analysis with the use of erythrocyte antigens of blood groups of animals as genetic markers is widely used for certification and verification of the accuracy of animal origin, characteristics of genotypic breed patterns, lines and populations, families, evaluation of their genetic proximity. [5]

Polymorphism of erythrocyte antigens raised the possibilities of objective assessment of ecological-genetic processes in populations of animals and realized the scientifically-based management of the selection process aimed at improvement of economic character of animals.

Holstein cattle (fig.1) are widely used as improving ones in many countries of the world thanks to their outstanding characteristics of productivity.

More than 43 thousand doses of semen of redand-white Holstein Friesians were brought into our 
country in 1976-77; 18 stud-bulls were imported in 1978. The lines of Reflection Sovereign (RS) and Inka Supreme Reflection 121004, Governor of Carnation 629472 are most widely presented ones.

The object and methodology of research. The breeding work with lines of red-and-white cattle at «Borodino" state stud farm has been done very carefully for a long time.

In 1980-s 1090 heifers of red-and-white Holstein breed arrived in the Russian Federation from Germany, one hundred of them arrived at JSC "Borodino stud-farm" of Krasnoyarsk region [7].

The analysis of the imported Holstein cattle and their reproduction showed that the breeding stock and stud-bulls belong to leading breed lines: Wis Burke Ideal [WBI] 933122, Reflection Sovereign [RS] 198998, Sealing Trygen Rocket [STR] 252803, Montvic Chieftain [MC] 95679, Inka Supreme Reflection [ISR] 121004 [8]. RS line includes a branch of Rosafe Citation [RC] 267150. Its characteristic feature is the presence of more than a half of bulls of red color in it. Fund-hope is the largest branch in MC line. The Siberian cattle are aboriginal in the region.

Mass improvement of aboriginal Siberian cattle in the region began in 1930. More than 100 Simmental bulls imported from Germany, Austria, Switzerland, Hungary, as well as a large number of domestic breeders of stud farms of Smolensk, Tambov regions and the Ukraine were brought into Krasnoyarsk region from 1931 to 1978. The absorptive crossing was the main method of breeding. Seven purebred bulls of Monbelyard breed were delivered into the region in 1979 [5, 8].

Since 1979 stud-bulls of Holstein breed have been delivered to the region from farms of Moscow and Sakhalin areas, Primorski Krai and Germany. The improvement of Simmental and purebred cattle with bulls of Holstein breed began in the region in 1979.

The program of developing Siberian red-andwhite dairy cattle was launched in the region on the basis of cross-breeding of Simmental cows and Holstein bulls. Shalimar (Shm) 2656070 line was initiated both through the bull Clapan 2124 imported from Germany in 1986 and individual stud-bulls whose sperm was received from the national Semen Bank.

Line WBI 933122 (from Holstein lines) in Krasnoyarsk region is presented by three branches: Pecular Bootmaker 1450228, Round Oak Elevation 1490007 and B. B. Pontica Modus 1196645.

Simmental cattle were represented as a set of six lines of animals. The largest one was Rafael $31113 C-635$ line $(\mathrm{n}=45)$, fewer animals belonged to Mergel $2122 \mathrm{ChS}-266$ line $(\mathrm{n}=38)$ and Signal 4863 ChS-239 line $(n=36)$, the lines of Vals 8349 COS -186 $(\mathrm{n}=23)$ and Sokol 19551 KSS-347 $(\mathrm{n}=$
18) don't include many animals, the smallest line is Fasadnik 624 SC-9 line $(n=8)$. Besides them there are cows of Swiss origin $(n=10)$ in the population which also belong to the Simmental breed.

Each breed group at the farm was multiline, and therefore there were very few lines. In this connection it is reasonable to combine the lines of purebred Holstein Friesians and their hybrids, but during the analysis of the breed groups they were described separately - a group of Simmental cattle, F1 hybrids of Simmental-Holstein cattle, purebred Holstein Friesians.

The stud farm Borodino was formed in April 1930 by "Bogradsky cattle-farmer 65" state farm downsizing. It specializes in purebred cattle raising. In 197032 Simmental bulls and 20 cows were imported to Borodino for the development of livestock breeding from Sychevsky state stud farm. In its time the stud farm delivered purebred animals not only for needs of the USSR, but also to Korea, Mongolia. The main direction of activity of the state stud farm was growing and realization of young breeders - heifers and breeding bulls of Simmental breed. Profitability reached $500 \%$, profit - from 1 to 1.5 million rubles per year. The stud farm was awarded the title of a farm of high culture of farming and cattle-breeding. In November 2001 "Borodino" stud farm was renamed into "Borodinsky stud farm" federal state unitary enterprise. [2]

The material for the analysis were the animals of Bostaurus species of red-and-white breed of state stud farm "Borodinsky", which is located to the south of Krasnoyarsk on the territory of Khakassia Republic in the mild climate of the steppe zone. All in all 2534 blood samples of cattle from state stud farm "Borodinsky" were tested.

Antigenic spectrum of red blood cells of cattle was determined by monogenetic testing in accordance with current instructions $[6,9,10,11]$.

Results of the research. Comparative analysis of Simmental cattle of "Borodinsky" state stud farm revealed both certain specificity of each line and the typicality of the whole number of the given breed group. The presence of $\mathrm{F}, \mathrm{W}, \mathrm{H}^{\prime} \mathrm{Z}, \mathrm{O}_{2}$, $\mathrm{A}_{2}, \mathrm{E}, \mathrm{O}^{\prime}$ antigens common for lines and the elimination of $\mathrm{P}_{2}, \mathrm{G}$ ", $\mathrm{U}$ ', $\mathrm{C}, \mathrm{U}, \mathrm{R}_{1}, \mathrm{Y}^{\prime}$ antigens were typical for a combined group of Simmental cattle of "Borodinsky" state stud farm (Table. 1).

There weren't fixed any recurrent phenogroups in multifactor B-system, but there were allocated two large monoblocks - $\mathrm{B}_{2} \mathrm{G}_{2} \mathrm{O}^{\prime}$ and $\mathrm{G}_{3} \mathrm{O}_{2} \mathrm{~V}^{\prime} \mathrm{O}^{\prime}$. Animals with WL' phenogroup were spread in C-system, and $\mathrm{W}$ and $\mathrm{L}^{\prime}$ components of this group were spread among alleles. Other singlefactor and two-factor alleles are also often met. In SU-system there were spread cows with $\mathrm{S}_{1} \mathrm{H}^{\prime}, \mathrm{H}^{\prime}$ phenogroups and ss recessive homozygote. $74.8 \%$ 
of the animals showed $\mathrm{H}^{\prime}$ allele, and that is the highest value of the occurrence in polymorphic systems. As for $\mathrm{S}_{1}$ and $\mathrm{S}_{1} \mathrm{H}$ 'alleles, indexes are also high. An extensive group of monoblocks is fixed much more seldom. In FV-system as well as on separate lines there is a distinct advantage of $\mathrm{F}$ phenotype over FV heterozygotes. There are also ff recessive forms. In AH-system there is a tendency of superiority of $\mathrm{A}_{2}$ allele over $\mathrm{Z}^{\prime}$ allele. Monofactor systems are abundantly presented in the group with high frequency of occurrence. Carriers of $\mathrm{Z}$ allele are observed more often, those of L allele - less often. J and $\mathrm{M}$ alleles are between them (table 1).

Thus, in general, there were fixed those ratios of phenotypes and genotypes that are characteristic for the main lines included in this aggregate before Holstein intrusion.

Holsteinized cattle in the "Borodinsky" state stud farm were presented by 6 lines: MC 95679 (n = 53) (Montvic Chieftain), RS 198998 (Reflection Sovereign) $(\mathrm{n}=52)$, a group of RC $267150(\mathrm{n}=$ 40), ShM (Shalimar) $2656070(\mathrm{n}=27)$, STR (Sealing Trygen Rocket) $252803(\mathrm{n}=18)$ and WBI $933122(\mathrm{n}=9)$. Comparative analysis of F1 gene pool of Holstinized lines at "Borodinsky" state stud farm reflects a high degree of similarity of these breeding groups according to their antigenic spectrum. $\mathrm{F}$ and $\mathrm{H}^{\prime}$ antigens are present in all groups with high frequency of occurrence.

Table1

Immunogenetic markers of Simmental cattle population of "Borodinsky" state stud farm

\begin{tabular}{|c|c|c|c|c|c|c|c|c|c|c|c|}
\hline \multicolumn{6}{|c|}{ Marking alleles } & \multicolumn{6}{|c|}{ Eliminating alleles } \\
\hline $\mathrm{A}$ & $\mathrm{B}$ & $\mathrm{C}$ & SU & $\mathrm{FV}$ & Моно & $\mathrm{A}$ & $\mathrm{B}$ & $\mathrm{C}$ & SU & $\mathrm{FV}$ & Моно \\
\hline $\mathrm{A}_{2}$ & $\begin{array}{l}\mathrm{O}_{2} \\
\mathrm{O}^{\prime}\end{array}$ & $\begin{array}{l}\text { W } \\
\text { E } \\
\text { EW }\end{array}$ & $\begin{array}{l}\mathrm{H}^{\prime} \\
\mathrm{S}_{1} \mathrm{H}^{\prime}\end{array}$ & $\mathrm{F}$ & $\mathrm{Z}$ & - & $\begin{array}{l}P_{2} \\
Y^{\prime} \\
G^{\prime},\end{array}$ & $\begin{array}{l}\mathrm{R}_{1} \\
\mathrm{C}^{\prime}\end{array}$ & $\begin{array}{l}\mathrm{U} \\
\mathrm{U}\end{array}$ & - & - \\
\hline
\end{tabular}

The number of eliminating antigens increases with decreasing size of the group, but in all groups this number includes $\mathrm{P}_{2}, \mathrm{U}, \mathrm{C}^{\prime}$ antigens, and in many groups these antigens are $\mathrm{B}^{\prime \prime}, \mathrm{Y}^{\prime}, \mathrm{U}^{\prime \prime}$. Specificity is observed in lines Shm (Shalimar) and STR (Sealing Trygen Rocket). In some lines of "Borodinsky" state stud farm there were revealed some specific features of the gene pool, namely: for RS (Reflection Sovereign) line they were Q' and $\mathrm{G}_{2}$ antigens, Q', $\mathrm{WX}_{2}, \mathrm{E}, \mathrm{R}_{2}$ alleles; for $\mathrm{Shm}$ (Shalimar) line $\mathrm{O}_{2}$ antigen acts as a marker and D', $\mathrm{I}^{\prime}, \mathrm{R}_{1}$ are eliminated; marker alleles are $\mathrm{cc}$ and heterozygous forms of FV. For WBI line $\mathrm{G}_{3}$ antigen is a line marker. D' eliminating antigen, H'U marker allele and absence of $Z^{\prime}$ allele are specific for STR (Sealing Trygen Rocket) line. For MC (Montvic Chieftain) line $\mathrm{O}^{\prime}$ is a marker allele.

F1 Holsteinized hybrids $(n=41)$ received at "Borodinsky" state stud farm is a group of animals with increased incidence of $\mathrm{F}, \mathrm{W}, \mathrm{Z}, \mathrm{O}_{2}, \mathrm{E}, \mathrm{H}^{\prime}, \mathrm{O}^{\prime}$, $\mathrm{X}_{2}$ antigens and rare $\mathrm{U}, \mathrm{U}^{\prime \prime}, \mathrm{H}^{\prime \prime}, \mathrm{P}_{2}$ antigens. As for $\mathrm{V}$-system, there have not been determined genotypic and phenotypic features in the group. In $\mathrm{C}$-system a high level of recessive alleles was recorded through cc homozygotes $(\mathrm{p}=0.037)$. Polymorphism is achieved with the participation of $\mathrm{W}, \mathrm{X}_{2}, \mathrm{EW}, \mathrm{L}$ ', $\mathrm{WX}_{2}, \mathrm{C}_{2} \mathrm{WL}^{\prime}$ monoblocks. A high concentration of cc recessive alleles as well as $\mathrm{H}^{\prime}$, $\mathrm{S}_{1} \mathrm{H}^{\prime}$ and $\mathrm{H}^{\prime} \mathrm{U}^{\prime}$ alleles is also noted in SU-system. $\mathrm{U}^{\prime \prime}$ is rarely found. F phenotype prevails in FVsystem, but FV heterozygotes are also noticeable and $\mathrm{ff}$ recessive alleles are present in the group as well. $\mathrm{AH}$ system is formed mainly by $\mathrm{A}_{2} ; \mathrm{Z}$ is significantly inferior to $A_{2}$ in prevalence. $Z$ and $J$ monofactor systems are represented abundantly, $\mathrm{L}$ system is rare, and $\mathrm{M}$ system is even rarer (Table 2).

Immunogenetic characteristics of Holsteinized cattle of "Borodinsky" state stud farm population

\begin{tabular}{|c|c|c|c|c|c|c|c|c|c|c|c|c|}
\hline \multirow[t]{2}{*}{ Populations } & \multicolumn{6}{|c|}{ Marking alleles } & \multicolumn{6}{|c|}{ Eliminating alleles } \\
\hline & $\mathrm{A}$ & $\mathrm{B}$ & $\mathrm{C}$ & $\mathrm{SU}$ & $\mathrm{V}$ & Mono & A & $\mathrm{B}$ & $\mathrm{C}$ & $\mathrm{SU}$ & $\mathrm{FV}$ & Mono \\
\hline $\begin{array}{l}\text { Purebred } \\
\text { Holsteins }\end{array}$ & & $\begin{array}{l}\mathrm{J}_{2}{ }^{\prime} \\
\mathrm{O}^{2} \\
\mathrm{O}^{\prime} \\
\mathrm{O}^{\prime} \mathrm{Q}^{\prime} \\
\mathrm{G}_{2}\end{array}$ & $\mathrm{X}_{2}$ & $H^{\prime}$ & $\begin{array}{l}F \\
V\end{array}$ & $\begin{array}{l}\mathrm{J} \\
\mathrm{Z}\end{array}$ & - & $\begin{array}{l}\mathrm{T}_{1} \\
\mathrm{Y}^{\prime} \\
\mathrm{B}^{\prime}, \\
\mathrm{I},\end{array}$ & $\mathrm{R}_{1}$ & $\mathrm{U}$ & - & - \\
\hline F1 hybrids & & $\begin{array}{l}\mathrm{O}_{2} \\
\mathrm{O}^{\prime}\end{array}$ & $\begin{array}{l}\mathrm{W} \\
\mathrm{X}_{2} \\
\mathrm{E}\end{array}$ & $\mathrm{H}^{\prime}$ & $\mathrm{F}$ & $\mathrm{Z}$ & - & - & - & $\begin{array}{l}\mathrm{U} \\
\mathrm{U}, \\
\mathrm{H}^{\prime},\end{array}$ & - & - \\
\hline
\end{tabular}


There are two different origin groups of purebred Holsteins in a population: imported cows of German origin and cows bred at the farm using the sperm of a semen central bank. Comparison of these two groups of Holsteins reflects both similarities and some differences in their gene pool. For example, there is a common antigenic spectrum for marker antigens. Serious differences were found in B-system, namely, only one $\mathrm{J}_{2}{ }^{\prime} \mathrm{O}^{\prime}$ monoblock was found in the combined group of Holsteins of local origin, and the frequency of its occurrence was low $(18 \%)$. Whereas in the German herd there were allocated 10 monoblocks and $\mathrm{O}_{2}$ - the most common of them - is present in $45.3 \%$ of the animals (Table 2 ). This is due to the fact that animals imported from Germany and collected in different regions of the country have common roots, and hence a common gene pool, so they have a greater number of alleles specific to cattle population of Germany. For purebred Holsteins of a combined group there are no such regularities because there are animals not only from different countries, but also ones bred using the sperm of breeders from other continents (the USA and Canada). Therefore, the gene pool of this group is more fragmented and polymorphous, which is confirmed by the analysis of not only B group, but also other blood group systems. $\mathrm{A}_{2}$ and $\mathrm{E}$ alleles are the most common in $\mathrm{C}$-system for German cattle, and monoblocks with $\mathrm{X}_{1}$ antigen are the least common. For local livestock with high rates of the same alleles $X_{1}$ is in fourth place in terms of its content in the group. One should also note the presence of a large number of recessive alleles in the combined cattle group, which is not the case with German Holsteins. A somewhat different picture is observed in SU-system. In both groups, the concentration peak falls to $\mathrm{H}^{\prime}$, and the situation with the presence of recessive forms in them is the same. In FV-system the animals of Germany show somewhat larger proportion of $\mathrm{F}$ phenotype and a smaller proportion of heterozygous forms, as opposed to local Holstein Friesian cows. In addition, they have a little more V phenotypes than ff recessives, and in the combined group the situation is the opposite one. In AHsystem the ratio between $A_{2}$ and $Z^{\prime}$ alleles among local Holsteins is close to equilibrium, while among purchased ones it is biased towards $\mathrm{A}_{2}$ allele. The majority of cows of Germanic origin are holders of Z-system, in contrast to the combined group: as for $\mathrm{J}$ and $\mathrm{L}$ systems, the situation is approximately the same, but M-system is abundant in the local herd, though it is almost disappearing among the cattle of Germany (Table 2).

Thus, we can state the fact that the animals from Germany which were purchased at one time and, therefore, taken from one ecological niche, have common roots of the gene pool formed in this ecosystem, as opposed to a simple group of animals, where each animal has its own genotype consistent with the historically formed ecogenesis individual for each animal. Therefore, such group of animals, because of its historical, geographical and ecological diversity can not have a gene pool with well-established elements fixing the belonging of a given group to a specific ecosystem.

If we want to trace the evolution of the gene pool in this population, it is necessary to compare the antigen-frequency characteristics of two original groups of animals - Simmental animals that existed on the farm before purchasing purebred or high half-bred Holstein cows, and F1 hybrids of Simmental-Holsteins, which, in fact, have been bred using the available Simmental and Holstein herd. When analyzing the changes that have occurred in F1 during Holsteinization, it should be mentioned that not only Simmental cows impregnated with purchased semen of purebred Holstein bulls but also Holstein-Friesian cows impregnated with the sperm of outstanding Simmental breeders were starting material for selection at "Borodinsky" state stud farm.

Conclusions. The analysis revealed that F1hybrids, retaining some features of the original forms, have acquired their own specific features, reflecting, thus, the contribution of all used studbulls with all their immunogenetic characteristics to the overall gene pool. As a result of cross-breeding there occurred a loss of both a part of antigens ( $U$ "and $\mathrm{H}^{\prime}$ ) and the alleles of B-system available in large quantities in the parental breed. In addition, in SU and FV systems there occurred the increase of proportion of recessive alleles and their homozygotes (Table. 2), which also indicates the loss of some informative genes, possibly carrying a positive correlation to the population. In C-system more resemblance was marked with Simmentals than with Holsteins. Thus, crossing two breeds caused the loss of genetic information inherent to original groups in this population of cattle and as a result $\mathrm{F} 1$ proved to be genetically poorer than the parent, which may lead to a breach in subsequent generations of adaptive mechanisms necessary for the existence of a population in a given ecosystem.

The population of red and white cattle of "Borodinsky" state stud farm was characterized by increased content of $\mathrm{F}, \mathrm{H}$ ', W, Z, X $, \mathrm{A}_{2}, \mathrm{E}, \mathrm{O}_{2}$ antigens and elimination of $\mathrm{P}_{1}, \mathrm{P}_{2}, \mathrm{~B}^{\prime \prime}, \mathrm{Y}^{\prime}$ antigens. Taking into account the fact that the alleles common to the population's component structures appeared with higher frequencies in the population of "Borodinsky" state stud farm, such alleles as $\mathrm{O}_{2}$, $\mathrm{G}_{3}, \mathrm{G}_{2}, \mathrm{O}^{\prime}, \mathrm{Q}^{\prime}, \mathrm{W}, \mathrm{X}_{2}, \mathrm{E}, \mathrm{C}_{2}, \mathrm{C}_{1}, \mathrm{H}^{\prime}, \mathrm{S}_{1}, \mathrm{~S}_{1} \mathrm{H}^{\prime}, \mathrm{F}, \mathrm{A}_{2}$, $\mathrm{Z}$, $\mathrm{J}$ can be considered as markers for this 
population. The presence of recessive alleles in B, SU- and C- systems as well as prevalence of recessive ff homozygotes over $\mathrm{V}$ phenotype and few holders of Z', M alleles (Table 2) are typical for the population.

\section{References:}

1. (2015) Molochnoe skotovodstvo Khakasii «khromaet na obe nogi». Available: http://prodmagazin.ru/2012/11/15/molochnoeskotovodstvo-hakasii-hromaet-na-obe-nogi/ (Accessed: 12.01.2015).

2. (2015) Borodino (Khakassia). Available: http://ru.wikipedia.org/ (Accessed: 12.01.2015).

3. Baker CMA (1982) The use of genetic relationships among cattle breeds in the formulation of rational breeding policies. A reexamination of the example of the south Devon and the Gelbvich. Anim. Blood Groups and Biochemical Genetics - 1982, V3-3, pp.199-213.

4. Burkat VP (1990) Breeding programs modeling. The development of artificial insemination of cattle. Issue 22, 1990. pp. 5255.

5. Eremina IY, Gerasimova LA, Lushenko AE (2014) Analysis of the Yenisey type Red-andwhite breed consolidation. Vestnik KrasSAU, 2014., No. 12, pp. 173-179.

6. Kharitonov TA, Sayapin AV, Gerasimova LA (2014) Mathematical analysis of genetic structure of Holstein cattle populations in some farms of Krasnoyarsk region. "Society and civilization in the twenty-first century: trends and prospects". No. 8 (12) 2014, pp. 42-46.

7. Prokhorenko DG (1989) Formation of a genealogical structure of Holstein cattle in farms of the RSFSR. Works VNIILM, 1989, pp.8-13.

8. Rendell E (1968) Using of blood groups and type of whey proteins to identify similarities and differences between populations of animals. Agriculture abroad. Livestock production. 1968. - № 10.

9. Sorokovoy PF (1974) Methodological recommendations on the study of blood groups in breeding cattle. Dubrovitsy: VIZH, 1974, pp.24.

10. Sorokovoy PF, Mashurov AM, Chernushenko VK (1990) and others. Recommendations for the development and implementation of immunogenetic method of increasing the efficiency of breeding dairy cattle. Alma-Ata, 1990. pp. 14.

11. (1985) Temporary instruction on the genetic control of reliability of agricultural animals origin. Moscow: Agropromizdat, 1985. pp.49. 